\title{
ANESTEZIJOS IR INTENSYVIOSIOS TERAPIJOS SLAUGYTOJŲ SU DARBU SUSIJUSIO PLAŠTAKŲ KONTAKTINIO DERMATITO POŽYMIŲ PAPLITIMAS IR PREVENCIJA
}

\author{
Anastasija Grinčenko, Zita Gierasimovič, Jurgita Stirblienė, Natalja Fatkulina \\ Vilniaus universiteto Medicinos fakulteto Sveikatos mokslu institutas
}

Raktažodžiai: anestezijos ir intensyviosios terapijos slaugytojai, plaštakų kontaktinis dermatitas, požymiai, prevencinès priemonès.

\section{Santrauka}

Didžiausiai plaštakų kontaktinio dermatito rizikos grupei priklauso anestezijos ir intensyviosios terapijos (AIT) slaugytojai, nes jų darbas, siekiant išvengti hospitalinių infekcijų, reikalauja dažnos rankų higienos ir ilgalaikio medicininių pirštinių mūvejjimo. Tyrimo tikslas - išanalizuoti anestezijos ir intensyviosios terapijos slaugytojų su darbu susijusio plaštakų kontaktinio dermatito požymių paplitimą ir prevenciją. Atlikta mokslinès literatūros analizè. Taikytas kiekybinis tyrimo metodas - anketinè apklausa. Tyrimo priemone parengta remiantis standartizuotu Šiaurès šalių profesinių odos ligų ir jų poveikio tyrimo klausimynu (angl. Nordic Occupational Skin Quastionnaire). Tyrimo priemonés patikimumui nustatyti ivertintas klausimyno vidinis nuoseklumas (Cronbach $\alpha=$ $0,867)$. Tiriamujų imtis formuota taikant netikimybini (tikslinį) atrankos būdą. İ tyrimą įtraukti AIT slaugytojai. Tyrimas vykdytas nuo 2020 m. gruodžio iki 2021 $\mathrm{m}$. kovo mènesio. Atlikta statistinè duomenų analizè. Skirtumai tarp grupių laikyti statistiškai reikšmingais, kai $p<0,05$. Tyrimo rezultatai parode AIT slaugytoju plaštakų kontaktinio dermatito riziką dèl jų darbe dažnos rankų higienos ir ilgą laiką mūvimų pirštinių. Dažniausi su darbu susijusio plaštakų kontaktinio dermatito požymiai: odos paraudimas, sausumas, pleiskanojimas, ittrūkimai, skilinejjimas, deginimas, perštejjimas, skausmingumas. Nustatyta, kad nutraukus dirginančiujų medžiagu poveikị (laisvalaikio metu), tiriamujų plaštakų odos būklè pagerejja. Vyresniojo amžiaus tiriamieji dažniau rankas dezinfekuoja (daugiau nei 20 kartų per darbo pamainą), nei plauna, pirštines mūvi ilgiau, nei jaunesnio amžiaus respondentai. Labiausiai plaštakų odą dirgina lateksinès pirštinès su talku. Jaunesniojo amžiaus tiriamieji dažniau rankas plauna (dažniausiai 7-10 kartų per darbo pamainą), nei dezinfekuoja. Rankų odos priežiūrai ar pajutę pradinius plaštakų kontaktinio dermatito požymius, respondentai darbe dažniausiai (2 -3 kartus per pamainą) naudoja drèkinamuosius kremus. Svarbios prevencinès priemonès, kurios labiausiai padètų sumažinti plaštakų kontaktinio dermatito požymių darbe atsiradimą, yra medicininių pirštinių mūvèjimo trukmès mažinimas, dirbant su odą dirginančiomis (dezinfekcinėmis) medžiagomis. Kiekvieną kartą nusiplovus rankas, rekomenduojama naudoti rankų kremus, nemūvèti pirštinių, kai tam nèra indikacijų.

\section{Ivadas}

Odos ligos sudaro daugiau nei 30 proc. visų užregistruotų su darbu susijusių susirgimų visame pasaulyje [1]. Kontaktinis dermatitas sudaro apie 90-95 proc. visų su darbu susijusių odos ligų atvejų [2-4]. Kontaktinis dermatitas apibréžiamas kaip odos uždegiminis procesas, kurị sukelia dirginančiosios medžiagos, tiesiogiai veikdamos rankų odos paviršių [4]. 80 proc. su darbu susijusio kontaktinio dermatito atvejų pakenkia plaštakoms [5,6]. Europos kontaktinių alergijų stebejjimo sistemos (angl. European Surveillance System on Contact Allergies) duomenimis, bene didžiausią su darbu susijusio plaštakų kontaktinio dermatito riziką patiria slaugos specialistai [7]. Pasak H. Fargly ir bendraautoriu (2019), plaštaku kontaktinio dermatito paplitimas tarp slaugytojų svyruoja nuo 16,5 iki 74 proc., priklausomai nuo darbo specifikos [8]. J. Stahmeyer su bendraautoriais (2017) atliktas mokslinis tyrimas, kuriame AIT slaugytojai vidutiniškai per darbo pamainą rankų higieną atlieka 134 kartus ir yra kontaktinio dermatito rizikos grupejje [9]. Plaštakų kontaktinio dermatito paveiktoje odoje kolonizuojasi auksinio stafilokoko (lot. Staphylococcus aureus) bakterijos, todèl yra rizika, kad slaugos personalas, sergantis plaštakų kontaktiniu dermatitu, gali užsikrèsti $S$. aureus ar meticilinui atspariomis Staphylococcus aureus (MRSA) bakterijomis ir 
kontaktiniu būdu perduoti šiuos mikroorganizmus pacientams, sukeldamas hospitalinę infekciją [10,11].

Tyrimo tikslas - išanalizuoti anestezijos ir intensyviosios terapijos slaugytojų su darbu susijusio plaštakų kontaktinio dermatito požymių paplitimą ir prevenciją.

\section{Tyrimo medžiaga ir metodai}

Atsižvelgiant ị darbo tikslą, buvo taikoma mokslinès literatūros analizè ir kiekybinis tyrimo metodas - anketinè apklausa, atliekama internetineje erdveje, naudojant Google Forms apklausos programinę ịrangą. Tyrimo priemonè parengta remiantis internetinejje erdvëje viešai prieinamu standartizuotu Šiaurès šalių profesinių odos ligų ir jų poveikio tyrimo klausimynu (angl. Nordic Occupational Skin Quastionnaire), kurio autoriai suteikè leidimą naudoti šį klausimyną su darbu susijusių odos ligų ir jų poveikio tyrimui. Klausimynas ị lietuvių kalbą buvo išverstas dvigubo vertimo metodu. Dalị tyrimo priemonès sudarè autoriaus parengti klausimai, pagrịsti mokslinès literatūros straipsniais. Tyrimo priemonès patikimumui nustatyti vertintas klausimyno vidinis nuoseklumas - skaičiuotas Cronbach alfa koeficientas. Atlikus skaičiavimus nustatyta, kad bendrasis tyrimo klausimyno vidinis nuoseklumas lygus 0,867 . Tyrimas buvo vykdomas nuo 2020 metų gruodžio iki 2021 metų kovo mėnesio. Tiriamujų imtis formuota taikant netikimybinį, tikslinị atrankos būdą. İ tyrimą įtraukti AIT slaugytojai. Statistinè duomenu analizè atlikta naudojant Microsoft Excel 2015 kompiuterinę programą ir statistikos paketą IBM SPSS Statistics 22.0. Nagrinėjamų požymių pasiskirstymui pasirinktoje imtyje ịvertinti taikyta aprašomoji duomenų statistika - absoliutūs (n) ir procentiniai (proc.) dažniai. Kiekybiniai duomenys pateikiami kaip aritmetiniai vidurkiai su standartiniu nuokrypiu $(\mathrm{m} \pm \mathrm{SN})$. Kiekybinių kintamųjų skirstinio normalumas tikrintas taikant Kolmogorov-Smirnov testą, duomenu analizei taikyti neparametrinès statistikos metodai. Dviejų grupių skirtumams vertinti taikytas Mann-Whitney U testas, triju - neparametrinis Kruskal-Wallis H kriterijus. Skirtumai tarp grupių laikyti statistiškai reikšmingais, kai p $<0,05$.

\section{Tyrimo rezultatai}

Atrankos kriterijus atitiko ir tyrime dalyvavo 113 AIT slaugytojų: 4 vyrai ir 109 moterys. Dèl mažo tyrime dalyvavusių vyrų skaičiaus, lyties aspektu duomenys nebuvo analizuojami. Jauniausiajam tyrimo dalyviui buvo 23 , vyriausiajam - 61 metai, respondentų amžiaus vidurkis (su standartiniu nuokrypiu) buvo $38,6 \pm 10,38$ metai. Ivertinus AIT slaugytojų darbo patirtị (metais) nustatyta mažiausia darbo patirtis 1 metai, didžiausia - 33 metai, respondentų darbo patirties vidurkis (su standartiniu nuokrypiu) $12,81 \pm 10,42$ metų. Analizuojant respondentų pasiskirstymą pagal išsilavinimą nustatyta, kad daugiau nei trečdalis $(41,6$ proc.) respondentų turi aukštaji neuniversitetinị išsilavinimą, aukštajj universitetini (bakalauro) - 26,6 proc., penktadalis respondentų (22,1 proc.) turi aukštaji universitetinį (magistro) ir mažiau nei dešimtadalis $(9,7$ proc.) tyrimo dalyvių pažymèjo, kad turi aukštesniojo išsilavinimo diplomą. Pagal darbo specifiką AIT slaugytojai pasiskirstè į 4 kategorijas: mažiau nei pusè $(45,1$ proc., $n=51)$ respondentų dirba tik reanimacijos ir intensyviosios terapijos skyriuje (RITS), ketvirtadalis (26,5 proc., $\mathrm{n}=30)$ tik operacinèje, mažiau nei ketvirtadalis $(23,1$ proc., $\mathrm{n}=26$ ) dirba kombinuotai (darbas operacineje ir RITS rotacijos principu), mažiau nei 5,3 proc. $(\mathrm{n}=6)$ tyrimo dalyvių

1 lentelè. Plaštakų kontaktiniam dermatitui būdingų požymių pasireiškimas per pastaruosius 12 mènesių (pagal amžių, proc.).

* Pastaba $p<0,005$

\begin{tabular}{|c|c|c|c|c|c|c|c|c|}
\hline \multirow[b]{2}{*}{ KD požymis } & \multicolumn{4}{|c|}{ 23-40 metų } & \multicolumn{4}{|c|}{ 41-61 metų } \\
\hline & dažnai & kartais & retai & niekada & dažnai & kartais & retai & niekada \\
\hline Paraudimas & $47,9 *$ & 27,1 & 12,5 & 12,5 & 13,8 & 20,0 & 38,5 & 27,7 \\
\hline $\begin{array}{l}\text { Odos sausumas (pleiskanoji- } \\
\text { mas) }\end{array}$ & $54,2 *$ & 22,9 & 12,5 & 10,4 & 27,7 & 20,0 & 29,2 & 23,1 \\
\hline Itrūkimai, odos skilinèjimas & $51,0 *$ & 32,4 & 8,3 & 8,3 & 20,0 & 21,5 & 30,8 & 27,7 \\
\hline Mažos vandeningos pūslelès & $33,3 *$ & 29,2 & 12,5 & 25,0 & 9,2 & 10,8 & 21,5 & 58,5 \\
\hline Papulès & $29,2 *$ & 14,6 & 27,1 & 29,1 & 7,7 & 7,7 & 27,7 & 56,9 \\
\hline $\begin{array}{l}\text { Staiga atsirandantys niežtintys } \\
\text { plotai }\end{array}$ & $33,3^{*}$ & 33,3 & 18,8 & 14,6 & 15,4 & 12,3 & 30,8 & 41,5 \\
\hline Niežèjimas & $39,6^{*}$ & 39,6 & 8,3 & 12,5 & 18,5 & 15,4 & 35,4 & 30,7 \\
\hline Deginimas, perštejjimas odoje & $43,8^{*}$ & 35,4 & 12,5 & 8,3 & 16,9 & 15,4 & 26,2 & 41,5 \\
\hline Odos jautrumas & $39,6^{*}$ & 29,2 & 12,5 & 18,7 & 20,0 & 21,5 & 32,3 & 26,2 \\
\hline Skausmingumas & $41,7 *$ & 25,0 & 25,0 & 8,3 & 12,3 & 16,9 & 23,1 & 47,7 \\
\hline
\end{tabular}


2 lentelè. Veiksniai, darbe labiausiai dirginantys plaštakų odą (pagal amžių, proc.).

*Pastaba $\mathrm{p}<0,005$

\begin{tabular}{|c|c|c|c|c|c|c|c|c|}
\hline \multirow{2}{*}{$\begin{array}{l}\text { Veiksniai } \\
\mathrm{n}=113\end{array}$} & \multicolumn{4}{|c|}{ 23-40 metų } & \multicolumn{4}{|c|}{ 41-61 metų } \\
\hline & $\begin{array}{l}\text { stipriai } \\
\text { dirgina }\end{array}$ & $\begin{array}{l}\text { vidutiniškai } \\
\text { dirgina }\end{array}$ & $\begin{array}{l}\text { silpnai } \\
\text { dirgina }\end{array}$ & $\begin{array}{l}\text { visai nedir- } \\
\text { gina }\end{array}$ & $\begin{array}{l}\text { stipriai } \\
\text { dirgina }\end{array}$ & $\begin{array}{l}\text { vidutiniškai } \\
\text { dirgina }\end{array}$ & $\begin{array}{l}\text { silpnai } \\
\text { dirgina }\end{array}$ & $\begin{array}{l}\text { visai ne- } \\
\text { dirgina }\end{array}$ \\
\hline $\begin{array}{l}\text { Dažnas rankų plo- } \\
\text { vimas }\end{array}$ & 25,0 & 66,7 & 8,3 & 0 & 43,1 & 29,2 & 24,6 & 3,1 \\
\hline $\begin{array}{l}\text { Dažna rankų dezin- } \\
\text { fekcija }\end{array}$ & $79,2 *$ & 4,2 & 16,6 & 0 & 41,5 & 32,3 & 20,0 & 6,2 \\
\hline $\begin{array}{l}\text { Netinkama plaštakų } \\
\text { odai pirštinių me- } \\
\text { džiaga }\end{array}$ & 58,3 & 22,9 & 4,2 & 14,6 & 33,8 & 43,1 & 10,8 & 12,3 \\
\hline $\begin{array}{l}\text { Ilgas pirštinių mūvè- } \\
\text { jimo laikas }\end{array}$ & $62,5^{*}$ & 22,9 & 14,6 & 0 & 46,2 & 21,5 & 29,2 & 3,1 \\
\hline
\end{tabular}

3 lentelè. Rankų plovimo ir dezinfekavimo periodiškumas pamainos metu (pagal amžių, proc.).

* Pastaba $p<0,005$

\begin{tabular}{|c|c|c|c|c|c|c|c|c|c|c|}
\hline \multirow{2}{*}{$\begin{array}{l}\text { Veiksniai } \\
n=113\end{array}$} & \multicolumn{5}{|c|}{ 23-40 metų } & \multicolumn{5}{|c|}{ 41-61 metų } \\
\hline & $\begin{array}{c}2-3 \\
\text { kartus }\end{array}$ & $\begin{array}{c}4-6 \\
\text { kartus }\end{array}$ & $\begin{array}{l}7-10 \\
\text { kartų }\end{array}$ & $\begin{array}{l}11-17 \\
\text { kartų }\end{array}$ & $\begin{array}{l}>20 \\
\text { kartų }\end{array}$ & 2-3 kartus & 4-6 kartus & 7-10 kartų & 11-17 kartų & >20 kartų \\
\hline Plaunu rankas & 0 & 25,0 & 56,2 & 16,7 & 2,1 & 3,1 & 16,9 & 24,7 & 21,5 & $33,8 *$ \\
\hline $\begin{array}{l}\text { Dezinfekuoju } \\
\text { rankas }\end{array}$ & 8,3 & 8,3 & 35,4 & 27,2 & 20,8 & 0 & 6,2 & 16,9 & 24,6 & $52,3 *$ \\
\hline
\end{tabular}

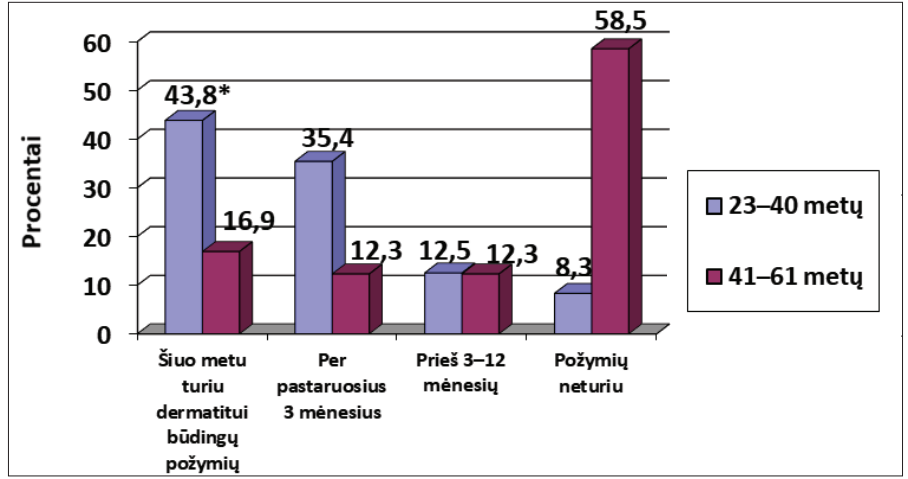

1 pav. Kontaktiniam dermatitui būdingų požymių pasireiškimas ant plaštakų odos (pagal amžių, proc.)

${ }^{*} p=0,001 ; p<0,05$, palyginus su amžiumi

dirba pabudimo (stebejjimo) palatoje. Analizuojant darbo krūvị nustatyta, kad mažiausias darbo valandų skaičius per savaitę yra 8 valandos, didžiausias -72 valandos, darbo valandų skaičiaus

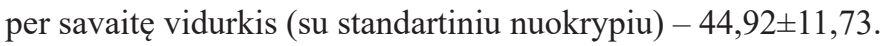

Kontaktiniam dermatitui būdingi požymiai. Nustatyti statistiškai reikšmingi skirtumai tarp plaštakų kontaktiniam dermatitui (KD) būdingų simptomų pasireiškimo per pastaruosius 12 mènesių ir respondentų amžiaus. KD simptomus dažniau patyre jaunesniojo amžiaus respondentai (1 lentelè).
Daugiau nei pusė 23-40 metų respondentų, ženkliai dažniau nei 41-61 metų respondentai, nurodè, kad per pastaruosius 12 ménesių jie dažnai patyrè odos pokyčius: sausumą, pleiskanojimą (atitinkamai 54,2 proc. $(\mathrm{n}=61)$ ir 27,7 proc. $(\mathrm{n}=31) ; \mathrm{p}=0,001)$ įtrūkimus, odos skilinejimą (atitinkamai 51,0 proc. $(\mathrm{n}=57)$ ir $20,0$ proc. $(n=23) ; p=0,001) .23-40$ metų respondentu dalis, lyginant su 41-61 metų respondentais, taip pat pažymejjo, kad dažnai patyrè paraudimą (atitinkamai $47,9$ proc. $(n=54)$ ir 13,8 proc. $(n=16) ; \mathrm{p}=0,001)$, deginimą, odos perštèjimą (atitinkamai 43,8 proc. $(n=49)$ ir 16,9 proc. $(n=19) ; p=0,001)$, niežèjimą (atitinkamai $39,6$ proc. $(n=45)$ ir 18,5 proc. $(n=21) ; p=0,001)$, odos jautrumą (atitinkamai 39,6 proc. $(n=45)$ ir 20,0 proc. $(n=23) ; p=0,011)$. Daugiau nei trečdaliui $23-40$ metų respondentų, dažniau nei 41-61 metų amžiaus grupejje, ant plaštakų odos pasireiškè mažos vandeningos pūslelès (atitinkamai 33,3 proc. $(\mathrm{n}=38)$ ir 9,2 proc. $(n=10) ; p=0,001)$, staiga atsirandantys niežtintys plotai (atitinkamai 33,3 proc. $(\mathrm{n}=38)$ ir 15,4 proc. $(\mathrm{n}=17) ; \mathrm{p}=0,001)$. Beveik trečdaliui 23-40 metų amžiaus grupès respondentų, dažniau nei 41-61 metų amžiaus grupejje pasireiškè papulès (atitinkamai 29,2 proc. $(n=33)$ ir 7,7 proc. $(n=9) ; p=0,001)$. Pastaruoju metu daugiau nei pusè $(\mathrm{n}=58)$ respondentų pastebejjo 
ant plaštakų odos kontaktiniam dermatitui būdingų požymių. Tyrimo duomenys leidžia nustatyti šių požymių atsiradimo periodiškumą (1 pav.).

Mažiau nei pusè (43,8 proc., $\mathrm{n}=49)$ tyrime dalyvavusių respondentų nurodė, kad apklausos metu turèjo plaštakų kontaktiniam dermatitui būdingų požymių ir dažną simptomų raišką. Didesnè 41-61 metų respondentų grupe (58,5 proc., $\mathrm{n}=66)$ ir mažesnè $23-40$ metų respondentų dalis ( 8,3 proc.) pažymèjo, kad būdingų dermatitui požymių neturi. Tyrimo metu nustatyti skirtingi veiksniai, dirginantys plaštakų odą (2 lentelè).

Nustatyta, kad 23-40 metų respondentai dažniau nei 41-61 metų amžiaus grupejje nurodè, kad dažna rankų dezinfekcija (atitinkamai 79,2 proc. ir 41,5 proc.; $\mathrm{p}=0,001$ ), ilgai mūvimos medicininès pirštinès (atitinkamai 62,5 proc. ir 46,2 proc.; $\mathrm{p}=0,036$ ) stipriai dirgina plaštakų odą. Tyrimo metu įvertinta, ar laisvu nuo darbo metu tyrime dalyvavusių respondentų plaštakų odos būklè pagerejja. Dauguma 23-40 metų amžiaus grupès respondentų (95,8 proc., $n=108)$ nurodè, kad laisvalaikio metu plaštakų odos būklè pagerejja, o 41-61 metų respondentai rečiau $(78,5$ proc., $n=89 ; p=0,008)$ nurodè, kad jų plaštakų odos būklè laisvu nuo darbo metu pagerèja ( 2 pav.).

Nustatytas statistiškai reikšmingas skirtumas pagal amžiaus grupes, vertinant rankų plovimo ir dezinfekavimo periodiškumą (3 lentelè).

Tyrimo rezultatai atskleidè, kad rankas dažniau (20 kartų ir daugiau) per darbo pamainą plauna 41- 61, nei 23-40 metų respondentai (atitinkamai 33,8 proc., $\mathrm{n}=38$ ir 2,1 proc., $\mathrm{n}=2 ; \mathrm{p}=0,001$ ). Rankas dažniau (daugiau nei 20 kartu per

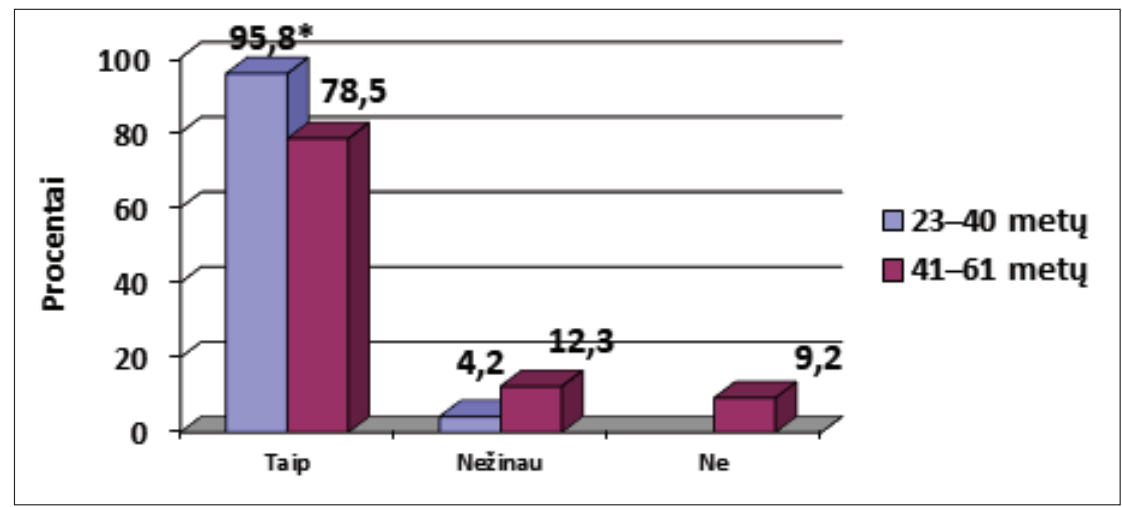

2 pav. Plaštakų odos pagerèjimas laisvu nuo darbo metu (pagal amžių, proc.)

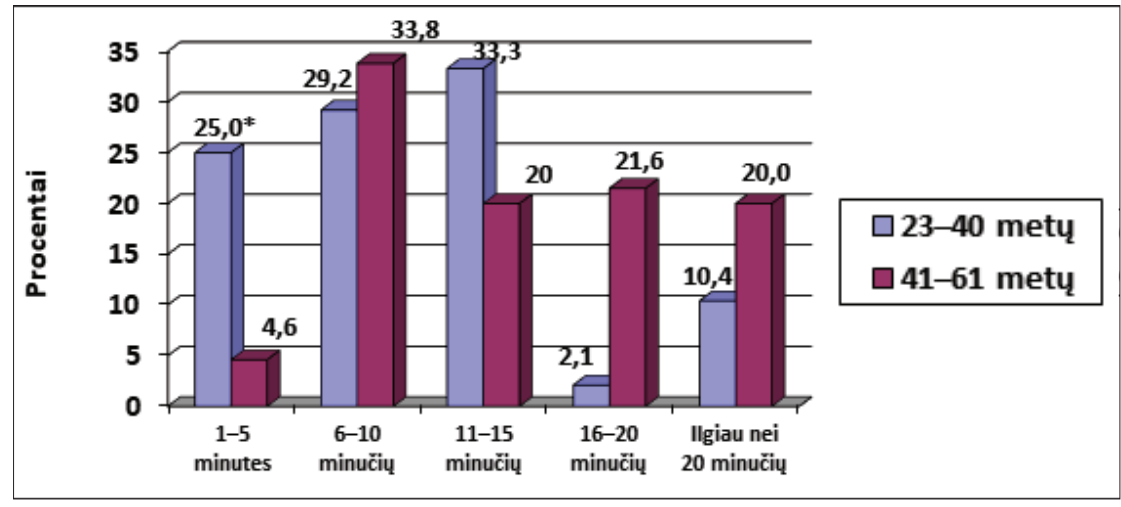

3 pav. Medicininių pirštinių mūvèjimo trukmė (pagal amžių, proc.) darbo pamainą) dezinfekuoja 41-61, nei 23-40 metų respondentai (atitinkamai 52,3 proc., $\mathrm{n}=59$ ir 20,8 proc., $\mathrm{n}=24 ; \mathrm{p}=0,001)$.

Pirštinių mūvèjimas. Tyrimu nustatyta, kokios pirštinių rūšys labiausiai dirgina plaštakų odą. Beveik puse tyrime dalyvavusių respondentu (47,8 proc., $n=54)$ nurodè, kad jų odą labiausiai dirgina lateksinès pirštinès su talku. Tik retais atvejais respondentai nurodè, kad jų odą dirgina polivinilinès $(2,7$ proc., $n=3)$ ir nitrilinès $(1,8$ proc., $\mathrm{n}=2)$ pirštinès, o 25,7 proc., n=29 tiriamujų pažymėjo, kad pirštinès nedirgina rankų odos. Nustatytas statistiškai reikšmingas medicininių pirštinių mūvèjimo trukmès skirtumas, priklausomas nuo respondentų amžiaus (3 pav.).

Rankų kremo naudojimas. Jaunesniojo amžiaus (23-40 metų) respondentai trumpiau mūvi medicinines pirštines (1-5 minutes), negu vyresniojo (41-60 metų) (atitinkamai $25,0$ ir 4,6 proc.; $p=0,007)$. Tyrimo rezultatai atskleide, kad daugiau nei trečdalis respondentų ( 36,3 proc.) plaštakų kontaktinio dermatito prevencijai darbe naudoja rankų kremus 2-3 kartus per darbo pamainą, mažesnė respondentų dalis (29,2 proc.) juos naudoja 4-6 kartus per darbo pamainą ir tik nedidelè dalis ( 7,1 proc.) nurodè, kad rankų kremų odos priežiūrai darbe nenaudoja. Daugiau nei puse respondentu pažymèjo, kad odos drèkinamuosius kremus jie dažniausiai naudoja pajutę pradinius plaštakų kontaktinio dermatito požymius: odos tempimą $(58,4$ proc., $\mathrm{n}=66$ ), esant sausai rankų odai (58,4 proc.). Rečiausiai respondentai odos drékinamuosius kremus naudoja prieš rankų plovimą $(64,6$ proc. $n=73)$.

Prevencinès priemonès. Daugelio (65,5 proc., $\mathrm{n}=74)$ respondentų nuomone, plaštakų kontaktinio dermatito požymių atsiradimą darbe labiausiai sumažintų medicininių pirštinių mūvëjimas, dirbant su dezinfekcinèmis 
priemonėmis. Kiek daugiau nei pusė tyrimo dalyvių (57,5 proc., $\mathrm{n}=65$ ) nurode, kad riziką sumažintų reguliarus drèkinamujjų kremų naudojimas kaskart po rankų plovimo, bei esant sausai odai. Mažesnè respondentų dalis (46 proc., $\mathrm{n}=52$ ) nurodé, kad plaštakų kontaktinio dermatito riziką sumažintų medicininių pirštinių nemūvèjimas, kai tam nèra indikacijų (pvz., kūno temperatūros matavimas nekontaktiniu termometru) ir trumpesnis jų mūvejjimo laikas. Pusé tyrime dalyvavusių 23-40 metų respondentų, priešingai nei 41-61 metų tiriamieji, dažniau buvo linkę sutikti su teiginiais, kad kontaktinio dermatito atsiradimą darbe labiausiai sumažintų pirštinių nemūvėjimas, kai rankos drègnos (atitinkamai 52,1 proc., $n=59$ ) ir 29,2 proc., $n=33 ; \mathrm{p}=0,014$ ). Jeigu pirštines teks mūvèti ilgiau nei 10 min., pirmiausia reikètų užsimauti vidines medvilnines, o ant jų - medicinines pirštines (atitinkamai 52,1 proc. $(\mathrm{n}=59)$ ir 9,2 proc. $(\mathrm{n}=10)$; $\mathrm{p}=0,001$ ). Kiek mažiau nei pusè 23-40 metų, skirtingai nei 41-50 metų tyrimo dalyvių, buvo linkę visiškai sutikti su teiginiais, kad plaštakų kontaktinio dermatito darbe riziką labiausiai sumažintų rankų plovimas, plaunant tik vizualiai užterštas rankas, ar po kontakto su infekuota medžiaga (atitinkamai 45,8 proc., $n=52$ ir 20 proc., $n=23 ; \mathrm{p}=0,003$ ), karšto vandens nenaudojimas rankoms plauti su muilu ir vandeniu (atitinkamai 43,8 proc., $n=49$ ir 29,2 proc., $n=33$; $\mathrm{p}=0,004)$. Daugiau nei trečdalis $23-40$ metų ir kiek mažiau 41- 60 metų respondentų nurodè, kad kontaktinio dermatito riziką darbe mažintų tokios priemonès: švelnus (netrinant) su muilu ir vandeniu nuplautų rankų nusausinimas servetèlemis (atitinkamai 37,5 proc., $n=42$ ir 24,6 proc., $n=28 ; \mathrm{p}=0,030$ ); muilo ir antiseptiko nenaudojimas vienu metu (atitinkamai 31,3 proc., $n=35$ ir 20 proc., $n=23$; $\mathrm{p}=0,025$ ).

\section{Rezultatų aptarimas}

Atlikto tyrimo rezultatai parodè, kad AIT slaugytojų plaštakų kontaktinio dermatito rizika susijusi su potencialiais plaštakų odos dirgikliais, kurie sukelia dažną kontaktinio dermatito požymių pasireiškimą. Labiausiai plaštakų odą dirgina dažnas rankų plovimas, rankų dezinfekavimas ir ilgą laiką mūvimos medicininès pirštinès. Tyrimo rezultatus patvirtina D. Zhang su bendraautoriais (2018) atliktas tyrimas, kurio rezultatai parode, kad rankų plovimas daugiau nei 20 kartų per dieną, ilgai mūvimos medicininès pirštinès ir ilgesné slaugytojo profesine darbo patirtis skatina plaštakų kontaktinio dermatito atsiradimą [12]. Tyrime nustatyta, kad plaštakų odos būklè dažniausiai pagerèja laisvalaikio metu. Panašaus pobūdžio problemą analizuoja O. Alluhayyan su bendraautoriais (2020) atliktame tyrime, kuriame vertinama sveikatos priežiūros darbuotojų odos būklè darbo metu ir poilsio dienomis. Tyrimo rezultatai parodè, kad poilsio dienomis respondentų odos būklẻ dažniausiai būna geresnè, palyginus su jos būkle darbo metu [13].

Mūsų atliktame tyrime, jaunesniojo amžiaus respondentai pamainos metu rankas dažniau plauna muilu, nei dezinfekuoja, tačiau vyresniojo amžiaus respondentai dažniau rankas dezinfekuoja. Prieštaringus rezultatus pateikia M. Mohaithef (2020) atliktas tyrimas, kuriame analizuojami slaugos specialistų rankų higienos įpročiai darbo metu. Gauti tyrimo rezultatai parode, kad nenustatytas statistiškai reikšmingas skirtumas tarp rankų plovimo su muilu ir rankų dezinfekcijos antiseptiniais tirpalais dažnio [14]. Mūsų tyrime nustatyta, kad vyresniojo amžiaus respondentai ilgiau mūvi medicinines pirštines, nei jaunesniojo. Gauti rezultatai patvirtina E. Omrane su bendraautoriais (2019) atlikto tyrimo rezultatus, kad didesnis medicininių pirštinių keitimo dažnis ir ilga medicininiu pirštinių mūvèjimo trukmè per darbo pamainą didina plaštakų kontaktinio dermatito riziką darbe [15].

Tyrimo dalyviai naudoja odos drèkinamuosius kremus, siekdami prižiūrèti plaštakų odą. Dažniausiai kremai naudojami pajutus pradinius plaštakų kontaktinio dermatito požymius. Užsienio šalių mokslininkai menkai tyrinejjo AIT slaugytojų taikomas plaštakų kontaktinio dermatito prevencines priemones. Mūsų tyrimo rezultatai sutampa su panašaus pobūdžio mokslininko A. Sanchez (2018) atliktu retrospektyviu tyrimu. Gauti tyrimo rezultatai parodè, kad plaštakų kontaktinio dermatito prevencija apima šiuos aspektus: tinkamas medicininių pirštinių mūvèjimas, racionali rankų higiena, apsauginių pirštinių mūvejjimas dirbant su cheminėmis medžiagomis, reguliarus drèkinamujjų kremų naudojimas [16].

\section{Išvados}

1. AIT slaugytojų darbe dažna rankų higiena ir ilgą laiką mūvimos medicininès pirštinès kelia plaštakų kontaktinio dermatito riziką. Jaunesniojo amžiaus respondentai plaštakų kontaktinio dermatito požymius patyrè dažniau, nei vyresniojo amžiaus tiriamieji. Dažniausi su darbu susijusio plaštakų kontaktinio dermatito požymiai: odos paraudimas, sausumas, ịtrūkimai, skilinèjimas, skausmingumas, deginimas, perštejimas. Nustatyta, kad laisvo nuo darbo metu respondentų plaštakų odos būklè pagerèja.

2. İvertinus AIT slaugytojų rankų higienos ịpročius darbe nustatyta, kad vyresniojo amžiaus respondentai rankų higieną atlikdavo dažniau, nei jaunesniojo amžiaus tiriamieji. Vyresniojo amžiaus respondentai dažniau rankas dezinfekuoja (daugiau nei 20 kartų per darbo pamainą), nei plauna, pirštines mūvi ilgiau, nei jaunesniojo amžiaus respondentai, o labiausiai plaštakų odą dirgina lateksinès pirštinès su talku. Jaunesniojo amžiaus respondentai dažniau rankas plauna, nei dezinfekuoja. Per darbo pamainą dažniausiai rankas plauna 7-10 kartų. 
3. Darbo metu rankų odos priežiūrai respondentai dažniausiai (2-3 kartus per pamainą ir pajutę pradinius plaštaku kontaktinio dermatito požymius) naudoja drèkinamuosius kremus. Svarbios prevencinès priemonès, kurios labiausiai padètų sumažinti plaštakų kontaktinio dermatito požymių darbe atsiradimą, yra medicininių pirštinių mūvejjimas dirbant su dezinfekcinèmis medžiagomis, drèkinamujų kremų naudojimas kiekvieną kartą nusiplovus rankas, pirštinių nemūvejjimas, kai tam nèra indikacijų ir mūvejjimo laiko trumpinimas.

\section{Literatūra}

1. Agner T, Elsner P. Handeczema: epidemiology, prognosis and prevention. Journal of the European Academy of Dermatology and Venereology 2020; 34(S1): 4-12.

https://doi.org/10.1111/jdv.16061

2. Salijuma E, Eglite M. Occupational skin symptoms among healthcare professionals in Latvia. East European Scientific Journal 2016; $6: 1-5$.

3. Franca D, Sacadura-Leite E, Fernendes-Almeida C, Filipe P. Occupational dermatose samong health care workersin a hospital centerin Portugal. Rev Bras Med Trab 2019; 17 (3): 285-291. https://doi.org/10.5327/Z1679443520190393

4. Milam EC, Nassau S, Banta E, Fonacier L, Cohen, D. E. Occupational Contact Dermatitis: An Update. Journal of Allergy and Clinical Immunology: In Practice 2020; 8 (10): 3283-3293. https://doi.org/10.1016/j.jaip.2020.08.004

5. Huzaifah H, Titi Rahmawati H. Prevalence of occupational handcontact dermatitis and its associated factors among staff nurses of a public hospitalin Selangor. International Journal of Public Health and Clinical Sciences, 2019; 6 (1):118-130. https://doi.org/10.32827/ijphcs.6.1.118

6. Ontario Agency for Health Protection and Promotion. Recommendations for the Prevention, Detection and Management of Occupational Contact Dermatitis in Health Care Settings. Ontario, 2019.

7. Holness DL. Occupational Dermatosis. Current Allergy and Asthma Reports 2019; 19(42):1-8.

https://doi.org/10.1007/s11882-019-0870-6

8. Fargly HAE, Mohammed MA, Ahmed RA. Hand skin problems: Prevalence and Risk Factors Among Nurses Working at Surgical Departments in Ministry of Health Hospitals. Assiut Scientific Nursing Journal 2019; 7 (16): 24-34.

https://doi.org/10.21608/asnj.2019.61136

9. Stahmeyer JT, Lutze B, von Lengerke T, Chaberny IF, Krauth C. Hand hygiene in intensive care units: a matter of time? Journal of Hospital Infection 2017;95:338-343.

https://doi.org/10.1016/j.jhin.2017.01.011

10. Madan I, Parsons V, Ntani G, Wright A, English J, Coggon D, McCrone P, Smedley J, Rushton L, Murphy C, Cookson $\mathrm{B}$, Lavender T, Williams $\mathrm{H}$. A behaviour change package to prevent hand dermatitis in nurses working in health care: The SCIN cluster RCT. Health Technology Assessment 2019; 23(58): 1-91.

https://doi.org/10.3310/hta23580

11. Gupta SB, Gupta A, Shah B, Kothari, P, Darall S, Boghara D, Sonkar S, Deo, K. Hand eczema in nurses, nursing auxiliaries and cleaners - A cross-sectional study from a tertiary hospital in western India. Contact Dermatitis 2018; 79(1): 20-25.

https://doi.org/10.1111/cod.13009

12. Zhang D, Zhang J, Sun S, Gao M, Tong A. Prevalence and risk factors of hand eczema in hospital-based nurses in Northern China. Australasian Journal of Dermatology 2018; 59(3):194197.

https://doi.org/10.1111/ajd.12672

13. Alluhayyan OB, Alshahri BK, Farhat A, Alsugair S, Siddiqui JJ, Alghabawy K, AlQefari GB, Alolayan WO, Abu Hashem IA. Occupational-Related Contact Dermatitis: Prevalence and Risk Factors Among Healthcare Workers in the Al'Qassim Region, Saudi Arabia During the COVID-19 Pandemic. Cureus 2020;12(10):1-12.

https://doi.org/10.7759/cureus.10975

14. Mohaithef MAL. Assessing Hand Hygiene Practices Among Nurses in the Kingdom of Saudi Arabia. The Open Public Health Journal 2020; 13(1): 220-226.

https://doi.org/10.2174/1874944502013010220

15. Omrane A, Amri C, Bouzgarrou L, Mahfoudh A, Khalfallah T, Akrout m, Henchi M.A, Ali HB. Nurses: workers particularly concerned by contact dermatitis in public hospital. Open Journal of Nursing 2019;9:313-328.

https://doi.org/10.4236/ojn.2019.93030

16. Sanchez A R. The Prevalence of Hand Dermatitis in Nurses: A Narrative Review Highlighting the Importance of Prevention. Journal of Dermatology \& Cosmetology 2018; 2(1): 48-48. https://doi.org/10.15406/jdc.2018.02.00036

PREVALENCE AND PREVENTION OF SIGNS OF WORK-RELATED HAND CONTACT DERMATITIS IN ANESTHESIA AND INTENSIVE CARE NURSES

A. Grinčenko, Z. Gierasimovič, J. Stirblienė, N. Fatkulina

Keywords: anesthesia and intensive care nurses, work-related, hand, contact dermatitis, signs, preventative measures.

Summary

Contact dermatitis accounts for about 90-95 percent of all cases of work-related skin diseases. Eighty percent of work-related contact dermatitis is caused by the hands, because they are most often in contact with allergens or irritants. Anesthesia and intensive care nurses are at the highest risk for hand contact dermatitis, as their work to prevent nosocomial infections requires frequent hand hygiene and prolonged wear of medical gloves. The aim of the study was to analyze the prevalence and prevention of signs of work-related hand contact dermatitis in anesthesia and intensive care nurses. The survey was conducted from December 2020 to March 2021 online using Google Forms survey software. Re- 
search involved 113 anesthesia and intensive care nurses: 4 men and 109 women. The results revealed that anesthesia and intensive care nurses at work are at risk of developing hand contact dermatitis due to frequent hand disinfection and prolonged wear of gloves. The most common signs of work-related hand contact dermatitis are redness, dryness / flaking of the skin, cracking of the skin, burning, itchy skin, and soreness of the skin. It was also found that during the time off work, the skin condition of the respondent's hands improved. Older respondents are more likely to disinfect their hands than wash and disinfect their hands more than 20 times per work shift, while younger respondents are more likely to wash their hands than disinfect and wash their hands, usually 7-10 times per work shift. Older respondents were found to wear gloves longer than younger respondents, latex gloves with talc being the most irritating to the skin of the hands. At work, respondents use moisturizing creams for hand skin care 2-3 times per shift and feel the initial signs of hand contact dermatitis. Important preventive measures to reduce the occurrence of signs of hand contact dermatitis at work: wear medical gloves when working with disinfectants, use hand creams every time after washing hands, do not wear medical gloves when there is no indication and wear them for as short a time as possible.

Correspondence to: zita.gierasimovic@mf.vu.lt

Gauta 2021-06-27 